\title{
Adaptation of conceptions of learning science questionnaire into Turkish and science teacher candidates' conceptions of learning science
}

\author{
Eralp Bahçivan ${ }^{1}$ and Serkan Kapucu ${ }^{2}$ \\ ${ }^{1}$ Department of Science Education, Abant İzzet Baysal University, Bolu, Turkey \\ 2Department of Elementary Education, Ağrı İbrahim Çeçen University, Ağrı, Turkey \\ For correspondence: eralpbahcivan@hotmail.com
}

\begin{abstract}
:
The purposes of this study were to (1) adapt an instrument "The Conceptions of Learning Science (COLS) questionnaire" into Turkish, and (2) to determine Turkish science teacher candidates' COLS. Adapting the instrument four steps were followed. Firstly, COLS questionnaire was translated into Turkish. Secondly, COLS questionnaire was administered to science teacher candidates $(n=382)$ from different universities in different regions of Turkey. After that, the exploratory factor analysis (EFA) was performed with 160 participants. Finally, the confirmatory factor analysis (CFA) was performed with remaining 219 participants. At the end of the validation processes six factors were retained. It was concluded that the adapted version of COLS questionnaire could produce valid and reliable scores on Turkish science teacher candidates.
\end{abstract}

Keywords: Science education, science teacher candidates, conceptions of learning science, adaptation study, exploratory factor analysis, confirmatory factor analysis.

\section{Introduction}

Science classrooms are complicated learning environments including considerable amount of variables concerning physical properties of learning environments, students' learning approaches and teacher interventions (Fraser, 2007). Each specific feature of a science learning environment relates to students' comprehensive learning. Science teachers' conceptions of learning play a key role in shaping how they behave and what teaching methodologies they will utilize in their classrooms (Entwistle \& Peterson, 2004; Lee, Johanson \& Tsai, 2008; Lonka, Joram \& Brayson, 1996; Tsai, 2009; Tsai, Ho, Liang, Lin; 2011). Therefore, these conceptions can affect teachers' approaches to teaching (Lonka et al., 1996) and in that way have the potential of affecting students' science learning.

A widely known pioneering study about the conceptions of learning was carried out by Saljo in 1979 (Eklund-Myrskog, 1998; Lee et al., 2008; Tsai et al., 2011). Saljo interviewed 90 individuals and asked them the meaning of learning for them. According to Saljo (1979), individuals had five different conceptions of learning. These were (1) increase of knowledge, (2) memorizing, (3) the acquisition of facts, procedures etc. which could be retained and/or utilized in practice, (4) abstraction of meaning, (5) interpretative process aiming at an understanding of reality. After the study of Saljo (1979), some researchers (e.g., Marshall, Summer \& Woolnough, 1999; Marton, Dall'Alba \& Beaty, 1993; Tsai, 2004) studied on different groups of individuals and different contexts to categorize conceptions of learning.

Marton et al. (1993) reconstructed the categorization of Saljo (1979) and added a new concept for conceptions of learning that a personal change. Marshall et al. (1999) made a new categorization for conceptions of learning very similar to the classification of Marton et al. (1993). In their study, they 
identified five different conceptions of learning: (1) memorizing definitions, equations and procedures, (2) applying equations and procedures, (3) making sense of physical concepts and procedures, (4) seeing phenomena in the world in a new way, (5) a change as a person. Tsai (2004) studied on high school students' conceptions of learning science. He asked students three questions which were "what do you understand by 'learning science'?", "how do you know when you have learned something about science?" and "how do you learn science?" to elicit their conceptions of learning science. After the analyses of the interview questions, he found seven categories for conceptions of learning science:

- Learning science as memorizing

- Learning science as preparing for tests

- Learning science as calculating and practicing tutorial problems

- Learning science as the increase of knowledge

- Learning science as applying

- Learning science as understanding

- Learning science as seeing in a new way (Tsai, 2004).

Lee et al. (2008) constructed an instrument "The Conceptions of Learning Science (COLS) questionnaire" based on the study of Tsai (2004) to investigate high school students' conceptions of learning in Taiwan. They used a five-point Likert scale anchored as $1=$ strongly disagree, $2=$ disagree, $3=$ no opinion, $4=$ agree, and $5=$ strongly agree. The final version of this questionnaire was composed of thirty one items and six factors. The names of the factors were given as (1) memorizing, (2) testing, (3) calculating and practicing, (4) increasing one's knowledge, (5) applying, (6) understanding and seeing in a new way. Exploratory factor analysis for COLS questionnaire showed that the reliability (Cronbach's alpha) coefficients for those factors respectively were $0.85,0.91,0.89,0.90,0.84$ and 0.91. These values suggested that COLS questionnaire might produce reliable scores for evaluating students' COLS.

When the instruments measuring some constructs such as attitude, conception or belief in science teaching and learning were examined in Turkey, there was no such an instrument measuring teachers' or teacher candidates' conceptions in science learning. For example, some researchers (e.g., Akbaş, 2010; Altınok, 2004; Nuhoğlu, 2008; Özkan, Tekkaya \& Çakıroğlu, 2002; Sarıkaya, 2004) measured attitudes and some others (e.g., Aypay, 2011; B1kmaz, 2002; Erdem, 2008; Özkan \& Tekkaya, 2011; Sarıkaya, 2004; Yaman, Koray \& Altunçekiç, 2004) measured beliefs related to science teaching and learning by developing or adapting of questionnaires in Turkey. The construct of conception has gained greater importance recently (Duarte, 2007; Entwistle \& Peterson, 2004; Tsai, 2009), because teacher candidates', teachers' and students' conceptions of learning seriously influenced their quality of the learning and teaching approaches (Duarte, 2007; Lee, Tsai, Chang \& Liang, 2009; Tsai; 2009). Therefore, we think that developing or adapting an instrument measuring Turkish science teacher candidates' COLS is required to analyze how they should be supported during their higher education years. In this regard, there are two purposes of this study. The first one is to adapt an instrument "The Conceptions of Learning Science (COLS) questionnaire" into Turkish. The second one is to determine Turkish science teacher candidates' COLS.

\section{Method}

\section{Research Procedure}

Adaptation of COLS questionnaire included four steps. These were (1) translation of the instrument into Turkish, (2) administration of the translated version, (3) conducting exploratory factor analysis (EFA), and (4) conducting confirmatory factor analysis (CFA). Prior to translation of the questionnaire 
we contacted with the developers of COLS questionnaire via e-mail and got permission. We translated COLS questionnaire items into Turkish independently. After discussing a few differences among the translated items, we reached a common version of COLS questionnaire. Then, we presented the translated version of the instrument to one English Language specialist to perform back-translation. At the end of the back-translation procedure we did not need to change anything on the instrument, since the language specialist reached the original version of COLS questionnaire. Finally, two academicians at Science Education Department and one academician at Turkish Language and Literature Department checked the translated version of COLS questionnaire (see Appendix). We made minor changes by considering the suggestions, related to covering multiple meanings of a few English terms utilized in the original COLS questionnaire. When we finalized the translation of COLS questionnaire, five-point Likert items were anchored at $5=$ strongly agree, $4=$ agree, $3=$ no opinion, $2=$ disagree, and $1=$ strongly disagree. Then, the questionnaire was administered in Turkey. We entered data into SPSS 20. Finally, we performed EFA on SPSS and CFA on Analysis of Moment Structures 18 (AMOS 18).

\section{Research Participants}

Turkish version of COLS questionnaire was administered to 382 (124 male and 258 female) science teacher candidates from seven different universities of the country. The participants were not able to be acknowledged as the national sample; however, they represented different regions of the country. They responded 31 items in approximately 15 minutes. At the end of this step the data was entered into SPSS. Three participants' papers possessing missing data were removed from the dataset.

\section{Data Analysis}

Data analysis included two steps. Firstly, we performed an exploratory factor analysis (EFA) with SPSS 20 including randomly selected 160 participants' data. At the beginning of the EFA, we examined Kaiser-Meyer-Olkin (KMO) measure of sampling and the Bartlett's test of sphericity to determine the appropriateness of sample for such analysis (Costello \& Osborne, 2005). Then, a principle component analysis with a varimax rotation was executed on the scores of COLS questionnaire. Lee et al. (2008) executed the principle component analysis with an oblique rotation in developing COLS questionnaire since the factors appeared to be correlated. In our analysis, factors did not present a high correlation; therefore, we decided to implement a varimax rotation in analysis. Retaining the number of factors, a combination of methods were considered such as eigenvalue $>1$, communality value $>0.5$, scree plots and maximizing cumulative percent of variance accounted for (Costello \& Osborne, 2005). Based on the EFA results, we extracted some items from the instrument if needed.

Secondly, we performed a confirmatory factor analysis (CFA) with AMOS 18 on the remaining data (219 participants). We presented the relations between latent and observed variables by standardized regression weights (factor loadings). We examined significance of the factor loadings against a level of 0.001 . Additionally, factor loadings below 0.40 were accepted as poor measures of the latent variables (Byrne, 2010). Furthermore, we evaluated fit of the confirmatory model with various fit indices. Chisquare per degree of freedom (CMIN/df) is a commonly used model fit index. Byrne (2010) stated that $\mathrm{CMIN} / \mathrm{df}$ values smaller than 2 represent a good fit of data. Additionally, root mean square error of approximation (RMSEA), goodness-of-fit Index (GFI), Tucker-Lewis index (TLI), the normed fit index (NFI) and comparative fit index (CFI) were also examined to evaluate model fit. RMSEA values closing to zero offers good fit (Byrne, 2010). GFI, TLI, NFI and CFI have values ranging from 0 to 1 , present good fit if larger than 0.9 . 


\section{Results}

As mentioned in previous chapters, adaptation of COLS questionnaire was achieved through EFA and CFA. For conducting the analysis properly, the participants $(n=379)$ were randomly divided into two parts. 160 participants for EFA and 219 participants for CFA were selected.

\section{Exploratory Factor Analysis for COLS questionnaire}

At the beginning of the EFA, we examined KMO measure of sampling and the Bartlett's test of sphericity to determine the appropriateness of sample for such analysis. The KMO measure of sampling adequacy index was found to be 0.85 , and Bartlett's test of sphericity was significant, chisquare $(465, \mathrm{n}=160)=2699.621, \mathrm{p}<0.0001$. Results pointed out that the sample was appropriate for the analysis. We also performed a principal components analysis with a varimax rotation on the original version of COLS questionnaire. We used various methods (e.g., eigenvalue $>1$, communality value $>$ 0.5 , scree plots and maximizing cumulative variance accounted for) in determination of item distribution which presents that six factors were retained. In determination of item-factor matching, the pattern coefficient (factor loading) of items should preferably get values greater than 0.40 on the relevance factor and less than 0.40 on all other factors (Stevens, 1996). As a result, 29 items were retained in the final version of COLS questionnaire. Item IK4 and IK5 were loaded on first and second factor, respectively instead of the fourth one. Since the loadings of these items on those factors were not interpretable, they were extracted from the dataset and the analysis was re-executed in the same way. As a result, KMO measure of sampling adequacy index was changed to be 0.83 , and Bartlett's test of sphericity was significant again, chi-square $(406, \mathrm{n}=160)=2450.135, \mathrm{p}<0.0001$. Results showed that the sample was still adequate to execute this analysis. The total variance explained increased from 62.58 to 63.27 when these items were extracted. The factor pattern and factor structural coefficients are presented in Table 1 also representing communalities (h2), means and the items' standard deviations.

Table 1. Rotated Factor Patterns, Communalities, Means, and Standard Deviations

\begin{tabular}{|c|c|c|c|c|c|c|c|c|c|}
\hline Item & $\begin{array}{c}\text { Factor } \\
\text { I } \\
\mathrm{P}\end{array}$ & $\begin{array}{c}\text { Factor } \\
\text { II } \\
\mathrm{P}\end{array}$ & $\begin{array}{c}\text { Factor } \\
\text { III } \\
\mathrm{P}\end{array}$ & $\begin{array}{c}\text { Factor } \\
\text { IV } \\
\mathrm{P}\end{array}$ & $\begin{array}{c}\text { Factor } \\
\mathrm{V} \\
\mathrm{P}\end{array}$ & $\begin{array}{c}\text { Factor } \\
\text { VI } \\
\mathrm{P}\end{array}$ & M & SD & h2 \\
\hline \multicolumn{10}{|c|}{ Factor I: Memorizing } \\
\hline M1 & 0,74 & 0,28 & $-0,05$ & $-0,09$ & $-0,04$ & $-0,14$ & 1,77 & 0,99 & 65,7 \\
\hline M2 & 0,81 & 0,28 & $-0,02$ & $-0,07$ & 0,01 & $-0,18$ & 1,83 & 0,98 & 77,0 \\
\hline M3 & 0,88 & 0,10 & 0,09 & 0,05 & 0,04 & $-0,07$ & 2,09 & 1,13 & 80,4 \\
\hline M4 & 0,58 & 0,00 & 0,30 & 0,06 & $-0,04$ & 0,05 & 2,86 & 1,18 & 53,9 \\
\hline M5 & 0,75 & 0,22 & $-0,03$ & $-0,02$ & $-0,01$ & $-0,13$ & 1,77 & 1,12 & 63,2 \\
\hline \multicolumn{10}{|c|}{ Factor II: Testing } \\
\hline $\mathrm{T} 1$ & 0,25 & 0,55 & $-0,09$ & $-0,25$ & 0,06 & $-0,09$ & 1,85 & 0,98 & 50,3 \\
\hline T2 & 0,20 & 0,63 & $-0,01$ & $-0,05$ & $-0,19$ & 0,05 & 2,16 & 1,12 & 67,8 \\
\hline T3 & 0,15 & 0,66 & $-0,14$ & 0,05 & $-0,20$ & $-0,23$ & 1,74 & 0,99 & 57,0 \\
\hline $\mathrm{T} 4$ & 0,14 & 0,67 & 0,03 & $-0,06$ & 0,12 & $-0,22$ & 1,86 & 0,99 & 53,8 \\
\hline T5 & 0,11 & 0,65 & 0,35 & 0,18 & 0,15 & $-0,11$ & 2,65 & 1,25 & 62,7 \\
\hline T6 & 0,15 & 0,68 & 0,22 & 0,20 & 0,11 & $-0,09$ & 2,69 & 1,18 & 64,6 \\
\hline \multicolumn{10}{|c|}{ Factor III: Calculate and practice } \\
\hline $\mathrm{CP} 1$ & $-0,05$ & 0,03 & 0,67 & $-0,01$ & $-0,20$ & 0,19 & 3,86 & 0,87 & 64,1 \\
\hline $\mathrm{CP} 2$ & 0,04 & $-0,21$ & 0,72 & 0,11 & $-0,04$ & 0,16 & 3,91 & 0,86 & 70,7 \\
\hline $\mathrm{CP} 3$ & 0,20 & 0,09 & 0,70 & 0,08 & 0,12 & 0,07 & 3,37 & 1,17 & 56,6 \\
\hline $\mathrm{CP} 4$ & 0,01 & 0,19 & 0,64 & $-0,03$ & 0,39 & $-0,09$ & 3,01 & 1,21 & 60,6 \\
\hline CP5 & 0,01 & 0,14 & 0,68 & 0,11 & 0,32 & 0,18 & 3,59 & 1,12 & 62,9 \\
\hline
\end{tabular}




\begin{tabular}{lccccccccc}
\multicolumn{8}{c}{ Factor IV: Increase of knowledge } \\
IK1 & $-0,05$ & 0,02 & 0,12 & 0,82 & 0,09 & 0,20 & 3,69 & 1,04 & 74,0 \\
IK2 & 0,01 & 0,08 & 0,06 & 0,75 & 0,14 & 0,18 & 3,71 & 1,04 & 66,2 \\
IK3 & $-0,03$ & $-0,08$ & 0,24 & 0,58 & 0,18 & 0,20 & 4,18 & 0,83 & 61,5 \\
& \multicolumn{7}{c}{ Factor V: Applying } \\
A1 & 0,10 & 0,08 & 0,20 & 0,11 & 0,77 & 0,09 & 3,78 & 0,99 & 71,4 \\
A2 & $-0,02$ & $-0,08$ & 0,21 & 0,07 & 0,66 & 0,13 & 3,87 & 0,93 & 67,1 \\
A3 & $-0,17$ & $-0,19$ & 0,12 & 0,08 & 0,41 & 0,11 & 4,04 & 0,98 & 58,2 \\
A4 & $-0,09$ & $-0,04$ & $-0,04$ & 0,14 & 0,52 & 0,08 & 3,73 & 1,01 & 55,7 \\
\multicolumn{7}{c}{ Factor VI: Understanding $\&$ seeing in a new way } \\
US1 & $-0,22$ & $-0,22$ & 0,05 & 0,19 & 0,17 & 0,62 & 4,20 & 0,80 & 59,1 \\
US2 & $-0,03$ & $-0,14$ & 0,04 & 0,14 & 0,08 & 0,80 & 4,16 & 0,82 & 69,0 \\
US3 & $-0,09$ & $-0,16$ & 0,13 & 0,07 & $-0,07$ & 0,86 & 4,22 & 0,81 & 79,5 \\
US4 & $-0,13$ & $-0,09$ & 0,11 & 0,22 & 0,16 & 0,73 & 4,24 & 0,74 & 65,0 \\
US5 & $-0,05$ & 0,03 & 0,09 & $-0,04$ & 0,14 & 0,80 & 4,25 & 0,79 & 66,6 \\
US6 & $-0,05$ & $-0,08$ & 0,10 & 0,03 & 0,14 & 0,81 & 4,26 & 0,81 & 69,7 \\
\hline
\end{tabular}

Note: $\mathrm{P}=$ Pattern coefficients; $\mathrm{M}=\mathrm{Mean} ; \mathrm{SD}=$ Standard deviation; and $\mathrm{h} 2=$ communalities of the measured variables.

As shown in Table 1, all the 29 items had communalities of at least 0.50 . The factors were nominated in the same way of Lee et al. (2008). These were memorizing (M), testing (T), calculate and practice $(\mathrm{CP})$, increase of knowledge (IK), applying (A), and understanding and seeing in a new way (US), respectively.

The final version of COLS questionnaire including the extracted items is presented in Appendix. Moreover, the reliability (Cronbach's alpha) coefficients of these factors $(n=160)$ were found as 0.84 , $0.81,0.80,0.82,0.79,0.90$, respectively, and the overall alpha was found as 0.82 . Results revealed that science teacher candidates' scores on the instrument presented sufficient reliability in assessment of their COLS.

\section{Confirmatory Factor Analysis for COLS questionnaire}

CFA was conducted by utilizing AMOS program on first-order confirmatory model. Therefore, while solely the factors of COLS questionnaire which were $\mathrm{M}, \mathrm{T}, \mathrm{CP}, \mathrm{IK}, \mathrm{A}$, and US depicted as the latent variables, the instrument items loaded under these factors in CFA were depicted as the observed variables. In CFA, standardized regression weights (factor loadings) were used to show the relation between latent and observed variables. Figure 1 represents the AMOS output including path diagram of CFA and Table 2 represents the results including completely standardized solution for COLS questionnaire item set. 


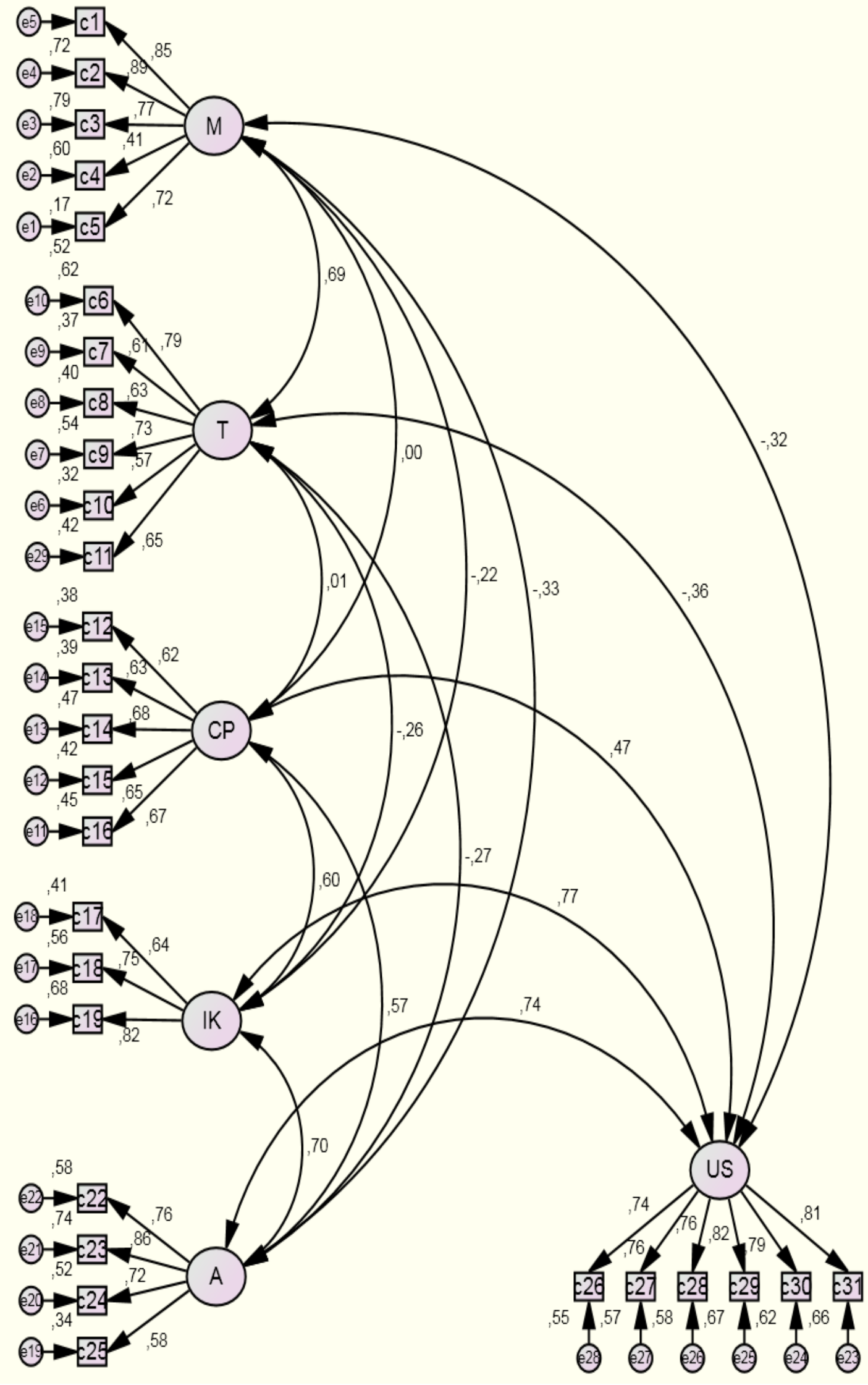

Figure 1. CFA path diagram 
Table 2. Results for Factor Loadings (FL) and Measurement Errors (ME)

\begin{tabular}{|c|c|c|c|c|}
\hline & Item & $\mathrm{FL}$ & $\mathrm{ME}$ & $p$ \\
\hline \multirow[t]{5}{*}{$\mathrm{M}$} & M1 & 0,85 & 0,09 & $<.001$ \\
\hline & M2 & 0,89 & 0,09 & $<.001$ \\
\hline & M3 & 0,77 & 0,08 & $<.001$ \\
\hline & M4 & 0,41 & 0,08 & $<.001$ \\
\hline & M5 & 0,72 & - & - \\
\hline \multirow[t]{6}{*}{$\mathrm{T}$} & $\mathrm{T} 1$ & 0,79 & 0,14 & $<.001$ \\
\hline & $\mathrm{T} 2$ & 0,61 & 0,12 & $<.001$ \\
\hline & T3 & 0,63 & 0,12 & $<.001$ \\
\hline & $\mathrm{T} 4$ & 0,73 & 0,12 & $<.001$ \\
\hline & T5 & 0,57 & - & - \\
\hline & T6 & 0,65 & 0,14 & $<.001$ \\
\hline \multirow[t]{5}{*}{$\mathrm{CP}$} & $\mathrm{CP} 1$ & 0,62 & 0,11 & $<.001$ \\
\hline & $\mathrm{CP} 2$ & 0,63 & 0,09 & $<.001$ \\
\hline & CP3 & 0,68 & 0,12 & $<.001$ \\
\hline & $\mathrm{CP} 4$ & 0,65 & 0,13 & $<.001$ \\
\hline & CP5 & 0,67 & - & - \\
\hline \multirow[t]{3}{*}{ IK } & IK1 & 0,64 & - & - \\
\hline & IK2 & 0,75 & 0,12 & $<.001$ \\
\hline & IK3 & 0,82 & 0,11 & $<.001$ \\
\hline \multirow[t]{4}{*}{ A } & A1 & 0,76 & 0,13 & $<.001$ \\
\hline & A2 & 0,86 & 0,14 & $<.001$ \\
\hline & A3 & 0,72 & 0,14 & $<.001$ \\
\hline & A4 & 0,58 & - & - \\
\hline \multirow[t]{6}{*}{ US } & US1 & 0,74 & 0,07 & $<.001$ \\
\hline & US2 & 0,76 & 0,07 & $<.001$ \\
\hline & US3 & 0,76 & 0,07 & $<.001$ \\
\hline & US4 & 0,82 & 0,07 & $<.001$ \\
\hline & US5 & 0,79 & 0,07 & $<.001$ \\
\hline & US6 & 0,81 & - & - \\
\hline
\end{tabular}

As can be seen in Figure 1 and Table 2, all the factor loadings are significant and presenting measurement errors smaller than 0.20 . In addition to the factor loadings and measurement errors, some of the fit indices were checked. A chi-square $(\chi 2)$ value of 1005.46 with 362 degrees of freedom (df); therefore, CMIN/df was found as 2.78. Other fit indices, CFI, GFI, TLI, NFI, RMSEA, were found as $0.91,0.87,0.90,0.94$, and 0.06 , respectively. Fit indices utilized in the analysis indicated a reasonable fit and confirmed the structure of COLS questionnaire.

\section{Descriptive Results for COLS questionnaire}

In following presentation of construct related evidences concerning the structure of COLS questionnaire, it is required to provide some descriptive results to fulfill research aims of the study. Interpretations were realized based on the CFA results, but not included the means and standard deviations of participants' item scores. Prior to CFA, executing EFA, these statistics were presented in Table 1. Instead, distributions of science teacher candidates' responses regarding each item can provide a better chance to make clear and understandable interpretations to the researchers of this study. Within this aim, Table 3 was constructed to show the distributions of participants' responses to each item in terms of frequencies and percentages. 
Table 3. Distributions of participants' responses to each item in terms of frequencies and percentages

\begin{tabular}{|c|c|c|c|c|c|c|c|c|c|c|c|}
\hline & \multirow[t]{2}{*}{ Items } & \multicolumn{2}{|c|}{$\begin{array}{l}\text { Strongly } \\
\text { Disagree }\end{array}$} & \multicolumn{2}{|c|}{ Disagree } & \multicolumn{2}{|c|}{$\begin{array}{c}\text { No } \\
\text { Opinion }\end{array}$} & \multicolumn{2}{|c|}{ Agree } & \multicolumn{2}{|c|}{$\begin{array}{l}\text { Strongly } \\
\text { Agree }\end{array}$} \\
\hline & & $\mathrm{f}$ & $\%$ & $\mathrm{f}$ & $\%$ & $\mathrm{f}$ & $\%$ & $\mathrm{f}$ & $\%$ & $\mathrm{f}$ & $\%$ \\
\hline M1 & $\begin{array}{l}\text { Learning science means } \\
\text { memorizing the definitions, } \\
\text { formulae, and laws found in a } \\
\text { science textbook. }\end{array}$ & 104 & 47,5 & 79 & 36,1 & 14 & 6,4 & 15 & 6,8 & 7 & 3,2 \\
\hline M2 & $\begin{array}{l}\text { Learning science means } \\
\text { memorizing the important } \\
\text { concepts found in a science } \\
\text { textbook. }\end{array}$ & 102 & 46,6 & 78 & 35,6 & 16 & 7,3 & 21 & 9,6 & 2 & 0,9 \\
\hline M3 & $\begin{array}{l}\text { Learning science means } \\
\text { memorizing the proper nouns } \\
\text { found in a science textbook that } \\
\text { can help solve the teacher's } \\
\text { questions. }\end{array}$ & 79 & 36,1 & 76 & 34,7 & 35 & 16 & 24 & 11 & 5 & 2,3 \\
\hline M4 & $\begin{array}{l}\text { Learning science means } \\
\text { remembering what the teacher } \\
\text { lectures about in science class. }\end{array}$ & 33 & 15,1 & 84 & 38.4 & 36 & 16,4 & 59 & 26,9 & 7 & 3,2 \\
\hline M5 & $\begin{array}{l}\text { Learning science means } \\
\text { memorizing scientific symbols, } \\
\text { scientific concepts, and facts. }\end{array}$ & 62 & 28,3 & 77 & 35,2 & 38 & 17,4 & 34 & 15,5 & 8 & 3,7 \\
\hline $\mathrm{T} 1$ & $\begin{array}{l}\text { Learning science means getting } \\
\text { high scores on examinations. }\end{array}$ & 97 & 44,3 & 78 & 35,6 & 20 & 9,1 & 18 & 8,2 & 6 & 2,7 \\
\hline $\mathrm{T} 2$ & $\begin{array}{l}\text { If there are no tests, I will not } \\
\text { learn science. }\end{array}$ & 71 & 32,4 & 98 & 44,7 & 25 & 11,4 & 21 & 9,6 & 4 & 1,8 \\
\hline T3 & $\begin{array}{l}\text { There are no benefits to learning } \\
\text { science other than getting high } \\
\text { scores on examinations. In fact, I } \\
\text { can get along well without } \\
\text { knowing many scientific facts. }\end{array}$ & 108 & 49,3 & 72 & 32,9 & 26 & 11,9 & 7 & 3,2 & 6 & 2,7 \\
\hline $\mathrm{T} 4$ & $\begin{array}{l}\text { The major purpose of learning } \\
\text { science is to get more familiar } \\
\text { with test materials. }\end{array}$ & 87 & 39,7 & 89 & 40,6 & 27 & 12,3 & 14 & 6,4 & 2 & 0,9 \\
\hline $\mathrm{T} 5$ & $\begin{array}{l}\text { I learn science so that I can do } \\
\text { well on science-related tests. }\end{array}$ & 43 & 19,6 & 82 & 37,4 & 27 & 12,3 & 50 & 22,8 & 17 & 7,8 \\
\hline $\mathrm{T} 6$ & $\begin{array}{l}\text { There is a close relationship } \\
\text { between learning science and } \\
\text { taking tests. }\end{array}$ & 40 & 18,3 & 71 & 32,4 & 52 & 23,7 & 48 & 21,9 & 8 & 3,7 \\
\hline $\mathrm{CP} 1$ & $\begin{array}{l}\text { Learning science involves a series } \\
\text { of calculations and problem- } \\
\text { solving. }\end{array}$ & 5 & 2,3 & 22 & 10 & 22 & 10 & 145 & 66,2 & 25 & 11,4 \\
\hline $\mathrm{CP} 2$ & $\begin{array}{l}\text { I think that learning calculation or } \\
\text { problem-solving will help me } \\
\text { improve my performance in } \\
\text { science courses. }\end{array}$ & 1 & 0,5 & 13 & 5,9 & 30 & 13,7 & 140 & 63,9 & 35 & 16 \\
\hline $\mathrm{CP} 3$ & $\begin{array}{l}\text { Learning science means knowing } \\
\text { how to use the correct formulae } \\
\text { when solving problems. }\end{array}$ & 8 & 3,7 & 32 & 14,6 & 46 & 21 & 111 & 50,7 & 22 & 10 \\
\hline
\end{tabular}


CP4 The way to learn science well is to 14 constantly practice calculations and problem solving.

CP5 There is a close relationship 4 between learning science, being good at calculations, and constant practice.

IK1 Learning science means acquirin knowledge that I did not know before.

IK2 I am learning science when the teacher tells me scientific facts that I did not know before.

IK3 Learning science means acquiring more knowledge about natural phenomena and topics related to nature.

A1 The purpose of learning science is learning how to apply methods I already know to unknown problems.

A2 Learning science means learning how to apply knowledge and skills I already know to unknown problems.

A3 We learn science to improve the quality of our lives.

A4 Learning science means solving or explaining unknown questions and phenomena.

US1 Learning science means understanding scientific knowledge.

US2 Learning science means understanding the connection between scientific concepts.

US3 Learning science helps me view natural phenomena and topics related to nature in new ways.

US4 Learning science means changing my way of viewing natural phenomena and topics related to nature.

US5 Learning science means finding a better way to view natural phenomena or topics related to nature.

US6 I can learn more ways about thinking about natural phenomena or topics related to nature by learning science. 
Distribution of responses showed that more than half of the participants strongly disagreed or disagreed with the statements of items loaded on memorizing and testing factors. This result proved that participants mostly did not think of learning science as memorization of scientific definitions, formulae, laws and special terms. Moreover, according to most of the science teacher candidates, being successful and getting high scores on science tests did not equal to learning science.

Participants mostly remarked agree or strongly agree on items of calculate and practice, increase of knowledge, and applying factors. Therefore, it is possible to mention, firstly, most of the science teacher candidates admitted that making practice and achieving calculations were essential parts of learning science processes. Secondly, according to them, learning science contributed to their knowledge of natural phenomena so increased their knowledge. Finally, they mostly viewed learning science as the application and implementation of scientific rules and laws to increase the quality of daily life and to increase the deficiencies related the knowledge of natural phenomena.

Results of the last factor of the instrument, understanding and seeing in a new way, presented similar direction of participants' response selections at $3^{\text {rd }}, 4^{\text {th }}$, and $5^{\text {th }}$ factors, but differentiated from them in terms of percentage distributions in selection of agree or strongly agree responses. In all items of this factor, more than $80 \%$ of responses were observed on positive alternatives. Therefore, almost all the teacher candidates thought that learning science was to understand scientific knowledge coherently and to gain new perspectives in order to interpret natural phenomena.

\section{Conclusions, Discussions, and Implications}

There were two purposes of this study. The first one was to adapt COLS questionnaire into Turkish and the second one was to present descriptive results of Turkish science teacher candidates' COLS. Firstly, translation of items was realized by the researchers who were majored on science education. In this step, suggestions of language specialists and science educators were taken in order to provide assurance of items' understandability by Turkish participants. We made the necessary changes and completed our translation.

Translated version of COLS questionnaire was administered to 382 science teacher candidates from seven different universities. To execute the EFA and CFA, the data was divided randomly into two subsets. In construction of subsets we considered two circumstances. First, EFA needs a sample of at least five times of the item number (Costello \& Osborne, 2005) and second, CFA needs a sample of at least 200 participants independently from number of items (Byrne, 2010). The translated version of the instrument included 31 items, so that EFA was required at least 155 participants which was the reason why 160 teacher candidates were included in the subset of EFA. Remaining 219 participants' data was utilized in CFA.

In EFA, KMO measure of sampling and the Bartlett's test of sphericity were examined to provide evidence for the appropriateness of sample such an analysis. Then, considering a combination of various methods (e.g. eigenvalues $>1$, communalities $>0,5$, scree plots and the variance explained by the sample), EFA was conducted. Because of loading two items on different factors and causing faulty interpretations in such a form, these two items were extracted and the analysis was conducted again. At the end, six factors were retained with Cronbach alpha reliabilities of $0.84,0.81,0.80,0.82,0.79$, 0.90 , respectively, and the overall alpha was found as 0.82 . Lee et al. (2008) observed the same factors with Cronbach alpha reliabilities of $0.85,0.91,0.89,0.90,0.84,0.91$, respectively, and the overall alpha was 0.91 . When compared with the developers' results, it can be concluded that adapted version of the instrument seems to produce valid and reliable scores. 
Moreover, to present further construct-related evidence CFA was conducted on the remaining data. In this analysis, factor loadings below 0.40 were accepted as poor measures of the latent variables. In addition to this, some of the fit indices, CMIN/df, CFI, GFI, TLI, NFI, and RMSEA, were examined to test the model fit. All items' factor loadings were found significant at level of 0.001 and greater than 0.40 . Fit indices were found as $2.78,0.91,0.87,0.90,0.94$, and 0.06 , respectively. Similar results were also observed by Lee et al. (2008). Based on the overall results, it can be concluded that adapted version of COLS questionnaire can produce valid and reliable scores on Turkish science teacher candidates.

Descriptive results of finalized instrument showed that memorization of scientific laws, formulae, etc... and achievement in science based testing had not critical importance in accordance to Turkish science teacher candidates' COLS. In addition to this, making practice of and achieving scientific calculations and contribution of learning science to their knowledge of natural phenomena seems as an essential part of participants' COLS. Moreover, they, mostly, view learning science as the application and implementation of scientific rules and laws to increase the quality of daily life. Finally, understanding scientific knowledge coherently and to gain new perspectives in order to interpret natural phenomena seems as the most essential part of almost all the participants. Our results were similar to that of Lee et al. (2009). They found that the participating Taiwanese teacher candidates in their study had high mean scores on the factors "increase of knowledge" and "understanding and seeing in a new way" as in our study. Therefore, it can be claimed that Turkish science teacher candidates' COLS may be similar to that of Taiwanese teacher candidates. In addition to this, the data of this study was collected among teacher candidates, while Lee et al. (2008) studied with high school students. Even though these studies had different samplings, the results obtained from the study of Lee et al. (2008) and ours were similar to each other. For example, the mean scores of each item within the factors found in our study were very close to mean scores of that found in Lee et al. (2008). We think that those similar results show that science teacher candidates and high school students may have similar COLS. Finally, the instrument COLS questionnaire should be administered to students and in-service teachers in Turkey. In this regard, new evidences for the validity of the Turkish version of COLS questionnaire can be collected. Additionally, what we can offer as the implicational suggestion is the development of an instrument focusing on conceptions of science teacher candidates' teaching ways. Such an instrument will create opportunities to science education researchers of analyzing how the conceptions of science teacher candidates affect their probable ways of teaching science.

\section{References}

Akbaş, A. (2010). Attitudes, self-efficacy and science processing skills of teaching certificate master's program (OFMAE) students. Eurasian Journal of Educational Research, 39, 1-12.

Altınok, H. (2004). Cinsiyetve başarı durumlarına göre ilköğretim 5.sını öğrencilerinin fen bilgisi dersine yönelik tutumları Eurasian Journal of Educational Research, 17, 81-91.

Aypay, A. (2011). Epistemolojik inançlar ölçeğinin Türkiye uyarlaması ve öğretmen adaylarının epistemolojik inançlarının incelenmesi. Eskişehir Osmangazi Üniversitesi Sosyal Bilimler Dergisi, 12(1), 1-15.

Bıkmaz, H. F. (2002). Fen öğretiminde öz-yeterlik inancı ölçeği. Ĕ̆itim Bilimleri ve Uygulama, 1(2), 197-210.

Byrne, B. M. (2010). Structural equation modeling with AMOS. Basic concepts, applications and programming. Taylor \& Francis Group: New York.

Costello, B. A., \& Osborne, J. W. (2005). Best practices in exploratory factor analysis: four recommendations for getting the most from your analysis. Practical Assessment Research \& Education, 10(7), 1-9.

Duarte, A. M. (2007). Conceptions of learning and approaches to learning in Portuguese students. Higher Education, 54(6), 781794.

Eklund-Myrskog, G. (1998). Students' conceptions of learning in different educational contexts. Higher Education, 35(3), 299-316.

Entwistle, N. J., \& Peterson, E. R. (2004). Conceptions of learning and knowledge in higher education: Relationships with study behaviour and influences of learning environments. International Journal of Educational Research, 41(6), 407-428.

Erdem, M. (2008). The effects of the blended teaching practice process on prospective teachers' teaching self - efficacy and epistemological beliefs. Eurasian Journal of Educational Research, 30, 81-98. 
Fraser, B. J. (2007). Classroom Learning Environments. In Handbook of Research on Science Education, ed. Sandra K. Abell, Norman G. Lederman, 103-124.

Lee, M.-H., Johanson, R. E., \& Tsai, C.-C. (2008). Exploring Taiwanese high school students' conceptions of and approaches to learning science through a structural equation modeling analysis. Science Education, 92(2)191-220.

Lee, M.-H., Tsai, C.-C., Chang, C.-Y., \& Liang, J.-C. (2009). The relationships between Taiwanese high school science teachers' conceptions of learning science and their approaches to teaching science. Paper presented at the Association for Science Teacher Education (ASTE) Annual Meeting, Hartford, CT.

Lonka, K., Joram, E., \& Bryson, M. (1996). Conceptions of learning and knowledge: Does training make a difference? Contemporary Educational Psychology, 21(3),240-260.

Marshall, D., Summer, M., \& Woolnough, B. (1999). Students' conceptions of learning in an engineering context. Higher Education, 38(3), 291-309.

Marton, F., Dall' Alba, G., \& Beaty, E. (1993).Conceptions of learning.International Journal of Educational Research, 19(3), 277-299.

Nuhoğlu, H. (2008). İlköğretim fen ve teknoloji dersine yönelik bir tutum ölçeğinin geliştirilmesi. İlköğretim Online, 7(3), 627638.

Özkan, Ö., Tekkaya, C., \& Çakıroğlu, J. (2002). Fen bilgisi aday öğretmenlerin fen kavramlarını anlama düzeyleri, fen öğretimine yönelik tutum ve öz yeterlik inançları, V. Fen ve Matematik Kongresi, Ankara.

Özkan, Ş., \& Tekkaya, C. (2011). Epistemolojik inançlar cinsiyete ve sosyo ekonomik statüye göre nasıl değişmektedir? Hacettepe Üniversitesi Ĕ̈itim Fakültesi Dergisi, 41, 339-348.

Saljo, R. (1979). Learning in the learner's perspective 1. Some commonsense conceptions. Gothenburg, Sweden: Institute of Education, University of Gothenburg.

Sarıkaya, H. (2004). Preservice elementary teachers' science knowledge, attitude toward science teaching and their efficacy beliefs regarding science teaching. Unpublished master's thesis for master's degree, Middle East Technical University, Ankara, Turkey.

Stevens, J. (1996). Applied multivariate statistics for the social science (3rd ed.). Mahwah, NJ: Erlbaum.

Tsai, C.-C. (2004). Conceptions of learning science among high school students in Taiwan: A phenomenographic analysis. International Journal of Science Education, 26(14), 1733-1750.

Tsai, C.-C. (2009). Conceptions of learning versus conceptions of web-based learning: The differences revealed by college students. Computers $\mathcal{E}$ Education, 53(4), 1092-1103.

Tsai, C.-C., Ho, H. N. J., Liang, J.-C., \& Lin, H.-M. (2011). Scientific epistemic beliefs, conceptions of learning science and selfefficacy of learning science among high school students. Learning and Instruction, 21(6), 757-769

Yaman, S., Koray, Ö. C., \& Altunçekiç, A. (2004).Fen bilgisi öğretmen adaylarının öz yeterlik inanç düzeylerinin incelenmesi üzerine bir araştırma. G.Ü. Türk Ĕ̆itim Bilimleri Dergisi, 3(2). 


\section{Appendix}

\section{Fen Öğrenimi Anlayışları Anketi}

M1. Fen öğrenmek, ders kitabında yer alan tanımların, formüllerin ve kanunların ezberlenmesi demektir.

M2. Fen öğrenmek, ders kitabında yer alan önemli kavramların ezberlenmesi demektir.

M3. Fen öğrenmek, ders kitabında yer alan ve öğretmen sorularının çözümüne yardımcı olabilen kavramlar ve birimler gibi özel isimlerin ezberlenmesi demektir.

M4. Fen öğrenmek, öğretmenin fen dersinde ne anlattığının hatırlanması demektir.

M5. Fen öğrenmek, bilimsel sembollerin, bilimsel kavramların ve gerçeklerin ezberlenmesi demektir.

T1. Fen öğrenmek, sınavlardan yüksek puanlar almak demektir.

T2. Fen derslerinde sınavlar olmazsa fen konularını öğrenemem.

T3. Fen öğrenmenin sınavlardan yüksek puanlar almak dışında bir faydası yoktur. Aslında, birçok bilimsel gerçeği bilmeden de kendimi iyi hissedebilirim.

T4. Fen öğrenmenin ana amacı sınav türlerine olan tanışıklı̆̆ı artırmaktır.

T5. Fen ile ilişkili testlerde daha başarılı olabilmek için fen öğrenirim.

T6. Fen öğrenme ile sınavlara grime arasında yakın bir ilişki vardır.

$\mathrm{CP} 1$. Fen öğrenimi bir takım hesaplamalar ve problem çözme içerir.

$\mathrm{CP} 2$. Hesaplama yapmayı ve problem çözmeyi öğrenmemin fen derslerindeki performansımı artıracağını düşünüyorum.

CP3. Fen öğrenmek, problem çözümlerinde doğru formüllerin nasıl kullanılacağının öğrenilmesi demektir.

CP4. İyi bir şekilde fen öğrenmenin yolu düzenli olarak hesaplama yapmak ve problem çözmektir.

CP5. Fen öğrenimi, hesaplamalarda iyi olma ve düzenli alıştırma yapma arasında yakın bir ilişki vardir.

IK1. Fen öğrenmek, daha önce bilmediğim bilgileri edinmek demektir.

IK2. Öğretmenim daha önce bilmediğim bilimsel gerçekleri açıkladığı zaman fen öğreniyorum.

IK3. Fen öğrenmek, doğa olayları ve doğaya yönelik konular hakkında daha çok bilgi edinmek demektir.

IK4. Fen öğrenmek, doğa hakkında daha çok gerçeği öğrenmeme yardımcı olur.*

IK5. Doğa olayları ve doğaya yönelik konular hakkında bilgimi artırdığım zaman fen öğrenirim.*

A1. Fen öğrenmenin amacı bildiğim metotları bilinmeyen problemlere nasıl uygulayacağımı öğrenmektir.

A2. Fen öğrenmek, sahip olduğum bilgi ve becerileri bilinmeyen problemlere nasıl uygulayacağımı öğrenmek demektir.

A3. Yaşam kalitemizi artırmak için fen öğreniriz.

A4. Fen öğrenmek, bilinmeyen soruları ve olayları çözmek veya açıklamak demektir.

US1. Fen öğrenmek, bilimsel bilgiyi anlamak demektir.

US2. Fen öğrenmek, bilimsel kavramlar arasındaki ilişkiyi bilmek demektir.

US3. Fen öğrenimi doğa olaylarına ve doğa ile ilgili konulara farklı açılardan bakmama yardımcı olur. US4. Fen öğrenmek, doğa olayları ve doğaya yönelik konular hakkındaki bakış açımın değişmesi demektir.

US5. Fen öğrenmek, doğa olayları veya doğaya yönelik konular hakkında daha iyi bir bakış açısı bulmak demektir.

US6. Fen öğrenerek doğa olayları veya doğaya yönelik konular hakkında yeni düşünme yöntemleri öğrenebilirim.

Note: The final Turkish version of COLS questionnaire does not include item IK4 and IK5. 